\title{
EFFECT OF SUMMER PRUNING, CLUSTER THINNING, GIBBERELLIN AND FUNGICIDE APPLICATION ON BUNCH ROT DISEASE OF GRAPEVINE CV. THOMPSON SEEDLESS.
}

Mahrous, H.A.H. ${ }^{1}$ and O. Y. Shalaby ${ }^{2}$

1- Plant Pathology Research Institute, Agricultural Research Centre, Giza , Egypt.

2- Plant Pathology department, faculty of Agriculture, Fayoum Univ. , Fayoum, Egypt.

\begin{abstract}
Two field trials with 15 years old grapevines cv. Thompson Seedless (highly susceptible cultivar) were conducted at Sadat City, Menofyia governorate, Egypt. In these trials, treatments consisted of summer pruning, i.e. (leaf removal , shoot removal, topping and the treatment with (leaf removal +shoot removal + topping) in addition to the control vines (without summer pruning). An additional trial, compared the cluster thinning treatment with the control ( without cluster thinning).All plots were established in a split -plot design with or without fungicides or gibberellin application .The above mentioned treatments were applied during the growing season starting at full bloom till veraison stage ( the beginning of ripening ) in order to control grapevine bunch rot disease.

The obtained results showed that the disease incidence and severity of bunch rot were best reduced by using any of the used gibberellin treatments compared to that of untreated vines. The greatest reduction in disease incidence and severity was occurred in the treatments with three sprays of gibberellin when the flower cluster was $10 \mathrm{~cm}^{3}$ long, Full Bloom and $6 \mathrm{~mm}$ in berries diameter stage which summer pruning is done. In additional trial, cluster thinning also reduced disease incidence and severity in nonsprayed control compared to the nonsprayed control ( without cluster thinning).

The greatest reduction in disease incidence and severity was recorded from the treatments with three sprays of the fungicide (Euparen M) at bloom, pre-close and veraison. Also, the produced fruit yield from treated vines was significantly higher during the first and the second seasons in comparison with that of untreated vines.

Keywords: bunch rot, disease incidence, disease severity, gibberellin ,cluster thinning, veraison stage, summer pruning.
\end{abstract}

\section{INTRODUCTION}

Grapevine (Vitis vinifera L.) is the leading fruit crop all over the world. In Egypt, grapevine occupies the second rank among fruit crops after citrus. However, the area under this economic crop was about 160005 feddans and the total grape production reached 1391749 tons (Anonymous, 2005).

Under the Egyptian environmental conditions grapevine is attacked by several diseases, among which powdery and downy mildews and fruit rot diseases are of great economic importance.

Bunch rot disease under Sadat City, Menofyia governorate environmental conditions is a serious disease of grapes (Vitis vinifera L.) caused by Alternaria geophila, Aspergillus niger, Aspergillus flavus, Botrytis 
cinerea, Cladosporium herbarum, and Rhizopus negricans (Farag,1992). In these instances, bunch rot infection of grape berries commonly occurs in cultivars with dense canopies or tight berry clusters. In Egypt, first symptoms of disease on susceptible cultivars are generally evident when fruit sugar levels begin to increase (veraison).

Many plant growth regulators are known to induce changes in disease susceptibility though altered metabolism of the host i.e., Gibberellin

Gibberellin is used at various concentrations for spraying grapes at different times and / or growth stages to achieve defined purpose of increasing fruit-set, increasing berry size, reducing the berry shrivel and / or loosening compact bunches in grapes (Weaver, 1976).

Besides the main effect of gibberellin application as a strong growth regulator, it is also has some effects on disease susceptibility of grapes. In this connection, Branas (1967) discussed the effect of several treatments including fungicides and gibberellin as individual or mixed treatment on the infection of grapes by B. cinerea. Also, Hopping (1976) mentioned that applying $\mathrm{GA}_{3}$ at $10 \mathrm{ppm}$ to seeded grape cv. Siebel 5455 reduced the number of clusters infected by Botrytis cinerea. Whereas, if $\mathrm{GA}_{3}$ was applied at the start of calyptra shedding, bunches were less favourable to $B$. cinerea infection than those treated at $50-100 \%$ calyptra fall. Mahadevan (1984) reported that gibberellin reduced the bunch rot caused by $B$. cinerea at concentration of $1.5 \times 10^{-5} \mathrm{M}$. Kumar and Gupta (1987) studied the effect of pre harvest application of certain growth regulators on the storage behavior of Perlette grapes at low temperature. Growth regulators, gibberellin (GA) reduced berry rot. Mahrous (1988) found that applying $\mathrm{GA}_{4+7}$ at $10 \mathrm{ppm}$ was more effective against grape berries rot of Roumi- red under vineyard conditions. Sarig et al. (1998) studied the effects of growth regulator application on disease susceptibility of grapes. Therefore, $\mathrm{GA}_{3}$ application (40 $\mathrm{mg} /$ liter at the 3-4 $\mathrm{mm}$ berry diameter stage) increased decay caused by Rhizopus stolonifer in several new seedless cultivars. Dokoozlian et al(2001) recorded that application of $\mathrm{GA}_{3}$ significantly reduced berry set and cluster compactness, as well as the amount of fruit per vine with bunch rot, compared to the control. Ferree et al (2003) mentioned that the treatment of individual clusters with $\mathrm{GA}_{3}$ decreased berries with rot but the differences were not always significant. Boccalon et al (2005) found that gibberellic acid was applied when $50 \%$ of flowers were opened, the berries rot was markedly reduced (by an average of $44 \%$ over vineyards). Tiku et al (2005) ) reported that when $\mathrm{GA}_{3}$ was applied with $60 \mathrm{ppm}$ at 15 days after full flowering., the incidence of grapevine bunch rot was decreased.

Concerning the effect of the summer pruning on the infection with bunch rot disease. Wind speed through grapevine canopies was increased markedly after leaf removal (English at al, 1989) and development of $B$. cinerea was decreased inversely with wind speed (Thomas, 1988). Research into other potential means of canopy management has shown positive effects of increased yield and higher quality fruit resulting from changes in canopy microclimate (Smart, 1985) Botrytis bunch rot of grape was significantly reduced by canopy management. Also integrating leaf removal with chemical control may reduce the need for multiple fungicide applications (Bettiga et al, 
1989). Rot reduction after leaf removal was greatest when leaves were pulled from the fruit zone on both sides of cordon - trained vines (Stapleton and Grand ,1992). Wolf et al (1990 ) found that the incidence of fruit rots of grapes was the highest in control and the lowest of vines topped to 10 leaves. Wolf et al (1986 ) mentioned that the vine by lateral shoot and/or basal leaf removal significantly reduced the incidence of bunch rot (Botrytis cinerea).. English et al (1993 ) reported that leaf removal significantly reduced canopy density and increased evaporative potential in vines of the hybrid grape cultivars Vignoles and Seyval Blanc. Cherif and Boubaker(1998) recorded that removal of leaves around clusters, when practiced two or three times during the season, reduced significantly Botrytis bunch rot development in vitro and in vivo. Also, they found that the tested fungicides, vinchlozoline and dichlofluanide were effective in inhibiting the germination of conidia of the pathogen and the development of Botrytis bunch rot.

Another potential method of reducing the incidence and severity of grapevine bunch rot disease is the use of cluster thinning. In this connection, the thinning of berries reduced significantly Botrytis bunch rot development (Cherif and Boubaker,1998 and Houma et al,1998). Smithyman et al (1998) found that the delaying cluster thinning until after fruit set decreased the incidence of botrytis bunch rot.

The aim of this study was to further investigate the use of gibberellic acid, summer pruning and cluster thinning alone or combined with fungicide applications for potential control of bunch rot disease.

\section{MATERIALS AND METHODS}

A field trail was conducted in two successive seasons, 2005 and 2006 in a 15 years old grapevines cv. Thompson Seedless commercial vineyard in Sadat City, Menofyia governorate, Egypt. Vines on this site were moderately vigorous, cane - trained, super - pruned and planted on a spacing of $3.5 \times$ $1.5 \mathrm{~m}$. supported on $\mathrm{Y}$ shape.

Methods of fertilization, irrigation and other cultural practices for grapevine were as recommended to commercial vineyard in this site.

To study the effect of gibberellin application a $2 \times 5$ split - plot design with 3 replicates was used to study subplot effects of gibberellin application were investigated in this trial. Spray timings were established according to growth stages of the grapevine. Treatments included single application of $\mathrm{GA}_{3}$ at $15 \mathrm{ppm}$,when cluster is $10 \mathrm{~cm}$ In long, Full Bloom at $15 \mathrm{ppm}$, and $6 \mathrm{~mm}$ in berries diameter stage at 20ppm. A fourth treatment included three sprays at the timings described before, and fifth treatment was a non sprayed control. The spray treatments were applied to the two inside rows of a fourrow block. In each treatment, one of these paired rows had the summer pruning treatment and the other was the control (without summer pruning).

\section{Summer pruning treatments:-}

1. Leaf removal: Leaves and laterals located opposite, one node above, and one node below each flower cluster were removed by hand at late bloom, resulting in window of exposed clusters 
2. Shoot removal: Shoots were removed at late bloom. All interspur and crown shoots were removed and spurs were thinned to two shoots.

3. Topping: Topping was done at late bloom with tope trimmers, shoots about $100 \mathrm{~cm}$. long were toped back $30-45 \mathrm{~cm}$

4. Leaf removal, shoot removal and Topping were done at late bloom

5. Control (unmanaged) without summer pruning

The fungicide applications (subplot) also were investigated in this trial.

Spray timings were established according to growth stages of the grapevine. Treatments included single application of Euparen M (Tolylfluanid) at the rate of $200 \mathrm{~g} / 100 \mathrm{~L} . W$. at bloom, preclose, and veraison (the beginning of ripening) stages. A fourth treatment included three sprays at the timings described, and fifth treatment was a non sprayed control. The spray treatments were applied to the two inside rows of a four- rows block. In each treatment, one of these paired rows had the cluster thinning treatment and the other was the control (without cluster thinning).

\section{Cluster thinning treatments:-}

Clusters berries were thinned when the berry diameter reached 4-6 $\mathrm{mm}$ by leaving the first five laterals shoulders, removing the subsequent three laterals Shoulders, leaving the subsequent three laterals, and removing the rest of cluster.

Bunch rot and yield evaluation were conducted at harvest. Three randomly selected vines from each treatment in each replicate were hand harvested and evaluated for incidence and severity of bunch rot and yield according to (Gubler et al., 1987)

Bunch rot incidence was evaluated by counting diseased clusters per vine. Disease severity was determined by counting rotted berries and converting these figures to a percent rot per cluster based on the average number of berries per cluster according to (Gubler et al., 1987)

Yields were obtained by taking cluster weights per vine.

Statistical analysis of the obtained results were carried out according to Snedecor and Cochran (1972).

\section{RESULTS AND DISCUSSION}

These experiments were carried out under vineyard conditions to determine the effect of gibberellin and a fungicide application, summer pruning and cluster thinning on the incidence and severity of bunch rot disease and yield of grapevine cv. Thompson Seedless.

Data presented in Table (1) indicate that the summer pruning treatments significantly reduced the incidence and severity of bunch rot disease. Orthogonal contrast analysis of the data indicated that disease incidence was significantly reduced from $45.33 \%$ in the control treatment to $33.67 \%$ when summer pruning was done. Summer pruning also, significantly decreased disease severity. Data show a reduction in disease severity from $15.13 \%$ per cluster in the control treatment to $10.75 \%$ per cluster in the summer pruning treatment. 
Gibberellin application at the flower cluster is $10 \mathrm{~cm}$ in long, Full Bloom and when berry diameter is $6 \mathrm{~mm}$ stages resulted insignificant reduction in disease incidence in the vines managed by summer pruning (Table 1). Similarly, application of gibberellin at the flower cluster is $10 \mathrm{~cm}$ in long, Full Bloom and when berry diameter is $6 \mathrm{~mm}$ significantly reduced the bunch rot incidence on summer pruning vines.

Table (1): Effect of gibberellin application and summer pruning practices on the incidence and severity of bunch rot disease and yield of grapevine cv. Thompson Seedless (during season, 2005).

\begin{tabular}{|c|c|c|c|c|c|c|}
\hline \multirow[b]{2}{*}{$\begin{array}{c}\text { Summer pruning } \\
\text { treatments }\end{array}$} & \multicolumn{6}{|c|}{ 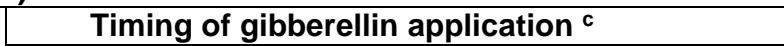 } \\
\hline & Control & $\begin{array}{l}10 \mathrm{Cm} \\
\text { In long }\end{array}$ & $\begin{array}{c}\text { Full } \\
\text { Bloom }\end{array}$ & $\begin{array}{c}6 \mathrm{~mm} \\
\text { berry } \\
\text { diameter }\end{array}$ & $1+2+3$ & Mean \\
\hline \multicolumn{7}{|c|}{ Disease incidence (Diseased clusters \%) ${ }^{a}$} \\
\hline Summer pruning ${ }^{\mathrm{b}}$ & 33.67 & 18.24 & 22.23 & 28,18 & 10.33 & $22.53^{*}$ \\
\hline Without summer pruning & 45.33 & 31.69 & 33.37 & 37.67 & 26.00 & 34.81 \\
\hline Means & 39.5 & $24.97^{*}$ & $27.8^{*}$ & $32.93^{*}$ & $18.17^{*}$ & \\
\hline \multicolumn{7}{|c|}{ Disease severity (Percent rot per cluster) } \\
\hline Summer pruning ${ }^{b}$ & 3023 & 05.76 & 06.36 & 07.18 & 04.24 & $10.75^{\star}$ \\
\hline Without summer pruning & 41.67 & 08.43 & 09.24 & 10.45 & 05.86 & 15.13 \\
\hline Means & 35.95 & 7.09 & $7.8^{*}$ & $8.81^{*}$ & $5.05^{*}$ & \\
\hline \multicolumn{7}{|c|}{ Yield/Vine $(\mathrm{Kg})^{\mathrm{a}}$} \\
\hline Summer pruning ${ }^{b}$ & 6.73 & 9.38 & 8.37 & 9.00 & 11.67 & $9.04^{*}$ \\
\hline Without summer pruning & 5.68 & 6.97 & 7.14 & 7.53 & 9.17 & 7.25 \\
\hline Means & 6.21 & $8.18^{*}$ & $7.76^{*}$ & $8.26^{*}$ & $10.42^{*}$ & \\
\hline \multicolumn{7}{|c|}{$\begin{array}{l}\text { = Results are expressed as an average of three replicates means differences with } \\
\text { orthogonal contrasts. Figures followed by an asterisk denote a significant }(P< \\
0.05) \text { effect from that treatment } \\
\text { = Summer pruning } \\
c=\text { Timing of gibberellin application: }- \\
1=\mathrm{GA}_{3} \text { at } 15 \mathrm{ppm} \text { when the flower cluster is } 10 \mathrm{~cm} \text { in long. } \\
2=\mathrm{GA}_{3} \text { at } 15 \mathrm{ppm} \text { when the flower cluster is full bloom } \\
3=\mathrm{GA}_{3} \text { at } 20 \mathrm{ppm} \text { when berry diameter is } 6 \mathrm{~mm}\end{array}$} \\
\hline
\end{tabular}

Gibberellin application on vines without summer pruning resulted in better disease control, but the greatest reduction in disease incidence and severity was occurred when applications of gibberellin were made at the flower cluster is $10 \mathrm{~cm}^{3}$ in long, Full Bloom and berry diameter is $6 \mathrm{~mm}$ stages in the first season(2005)

In the second season, it is clear from the data in Table (2) that all treatments showed the same trend of the data obtained in the first season.

The obtained results (Table, 2) indicate that disease incidence was significantly reduced from $43.67 \%$ in the control treatment to $35.33 \%$ when summer pruning was made. Summer pruning also decreased significantly disease severity. Data(Table, 2) show a reduction in disease severity from $15.75 \%$ per cluster in the control treatment to $11.32 \%$ per cluster in the summer pruning treatment. 
Table (2): Effect of gibberellin application and summer pruning practices on the incidence and severity of bunch rot disease and yield of grapevine cv. Thompson Seedless (during season, 2006).

\begin{tabular}{|c|c|c|c|c|c|c|}
\hline \multirow[b]{2}{*}{$\begin{array}{l}\text { Summer pruning } \\
\text { treatments }\end{array}$} & \multirow[b]{2}{*}{ Control } & \multicolumn{4}{|c|}{ 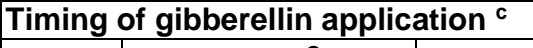 } & \multirow[b]{2}{*}{ Mean } \\
\hline & & $\begin{array}{l}10 \mathrm{Cm}^{3} \\
\text { In long }\end{array}$ & $\begin{array}{l}\text { Full } \\
\text { Bloom }\end{array}$ & $\begin{array}{c}6 \mathrm{~mm} \\
\text { berry } \\
\text { diameter }\end{array}$ & $1+2+3$ & \\
\hline \multicolumn{7}{|c|}{ Disease incidence (Diseased clusters \%) ${ }^{\mathrm{a}}$} \\
\hline Summer pruning ${ }^{b}$ & 35.33 & 20.17 & 23.16 & 27.76 & 9.67 & $23.22^{*}$ \\
\hline Without summer pruning & 43.67 & 32.76 & 35.63 & 39.83 & 23.43 & 35.06 \\
\hline Means & 39.50 & $26.46^{*}$ & $29.39^{*}$ & $33.79^{*}$ & $16.55^{\star}$ & \\
\hline \multicolumn{7}{|c|}{ Disease severity (Percent rot per cluster) ${ }^{a}$} \\
\hline Summer pruning ${ }^{b}$ & 31.45 & 5.26 & 7.18 & 7.97 & 4.73 & $11.32^{*}$ \\
\hline Without summer pruning & 43.53 & 8.13 & 9.67 & 11.24 & 6.17 & 15.75 \\
\hline Means & 37.49 & $6.69^{*}$ & $8.43^{*}$ & $9.61^{*}$ & $5.45^{*}$ & \\
\hline \multicolumn{7}{|c|}{ Yield/Vine $(\mathrm{Kg})^{\mathrm{a}}$} \\
\hline Summer pruning ${ }^{b}$ & 6.15 & 9.87 & 9,27 & 10.37 & 11.35 & $9.40^{*}$ \\
\hline Without summer pruning & 5.85 & 6.35 & 6.97 & 7.63 & 9.16 & 7.19 \\
\hline Means & 6.00 & 8.11 & $8.12^{*}$ & $9.00^{*}$ & $10.26^{*}$ & \\
\hline
\end{tabular}

${ }^{a}=$ Results are expressed as an average of three replicates means differences with orthogonal contrasts. Figures followed by an asterisk denote a significant $(\mathbf{P}<$ 0.05 ) effect from that treatment

${ }^{b}=$ Summer pruning

c = Timing of gibberellin application: -

$1=\mathrm{GA}_{3}$ at 15ppm when the flower cluster is $10 \mathrm{~cm}$ in long.

$2=\mathrm{GA}_{3}$ at $15 \mathrm{ppm}$ when the flower cluster is full bloom

$3=\mathrm{GA}_{3}$ at 20 ppm when berry diameter is $6 \mathrm{~mm}$

Another potential method for reducing the incidence and severity of grapevine bunch rot disease is the use of cluster thinning. In this connection, data (Table, 3) show clearly that the cluster thinning treatment significantly reduced incidence and severity of bunch rot. Orthogonal contrast analysis of the data indicated that disease incidence was significantly reduced from $44.52 \%$ in the control treatment to $38.67 \%$ when clusters were thinned. Cluster thinning also significantly decreased disease severity. Data (Table, 3) show a reduction in disease severity from $15.33 \%$ per cluster in the control treatment to $11.34 \%$ per cluster in the cluster thinning treatment.

Single fungicide (Euparen M) application was done at bloom, preclose and veraison stages resulted insignificant reduction in disease incidence in the vines managed by cluster thinning (Table,3). Similarly, Euparen $\mathrm{M}$ applications at bloom, preclose and veraison stages significantly reduced bunch rot incidence on cluster thinning vines. Fungicide (Euparen $\mathrm{M}$ ) application on vines without cluster thinning resulted in better disease control, but the greatest reduction in incidence and severity was occurred when applications of Euparen $\mathrm{M}$ were made at bloom, preclose and veraison stages in the first season. 
Table (3): Effect of cluster thinning and the fungicide application on the incidence and severity of bunch rot disease and yield of grapevine cv. Thompson Seedless (during season, 2005).

\begin{tabular}{|c|c|c|c|c|c|c|}
\hline \multirow[b]{2}{*}{$\begin{array}{l}\text { Cluster thinning } \\
\text { treatments }\end{array}$} & \multirow[b]{2}{*}{ Control } & \multicolumn{4}{|c|}{ Timing of a fungicide application ${ }^{c}$} & \multirow[b]{2}{*}{ Mean } \\
\hline & & $\begin{array}{c}\text { Full } \\
\text { Bloom }\end{array}$ & $\begin{array}{l}\text { Pre- } \\
\text { close }\end{array}$ & Veraison & $\begin{array}{l}\text { Bloom+ } \\
\text { Preclose + } \\
\text { Veraison }\end{array}$ & \\
\hline \multicolumn{7}{|c|}{ Disease incidence (Diseased clusters \%) ${ }^{\mathrm{a}}$} \\
\hline cluster thinning ${ }^{\mathrm{b}}$ & 38.67 & 21.33 & 24.67 & 27,00 & 15.21 & $25.37^{*}$ \\
\hline without cluster thinning & 44.52 & 32.86 & 36.93 & 38.14 & 30.67 & 36.62 \\
\hline Means & 41.59 & $27.09^{*}$ & $30.8^{*}$ & $32.57^{*}$ & $22.94^{*}$ & \\
\hline \multicolumn{7}{|c|}{ Disease severity (Percent rot per cluster) $^{a}$} \\
\hline cluster thinning ${ }^{b}$ & 31.56 & 5.63 & 7.26 & 8.13 & 4.14 & $11.34^{\star}$ \\
\hline without cluster thinning & 42.14 & 7.97 & 9.13 & 10.86 & 6.53 & 15.33 \\
\hline Means & 36.85 & $6.8^{*}$ & $8.19^{*}$ & $9.49^{*}$ & $5.33^{*}$ & \\
\hline \multicolumn{7}{|c|}{ Yield/Vine (Kg) ${ }^{\mathbf{a}}$} \\
\hline cluster thinning ${ }^{\mathrm{b}}$ & 7.65 & 9.67 & 8.46 & 8.86 & 11.24 & $9.18^{*}$ \\
\hline without cluster thinning & 6.14 & 7.53 & 6.76 & 7.13 & 8.13 & 7.14 \\
\hline Means & 6.89 & $8.6^{\star}$ & $7.61^{*}$ & $7.99^{\star}$ & $9.68^{*}$ & \\
\hline \multicolumn{7}{|c|}{$\begin{array}{l}\text { a=Results are expressed as an average of three replicates means differences with } \\
\text { orthogonal contrasts. Figures followed by an asterisk denote a significant }(P< \\
0.01) \text { effect from that treatment }\end{array}$} \\
\hline
\end{tabular}

In the second season, it is clear from the data $(T a b l e, 4)$ that all treatments showed the same trend of the data obtained in the first season.

Table (4): Effect of cluster thinning and the fungicide application on the incidence and severity of bunch rot disease and yield of grapevine cv. Thompson Seedless (during season,2006).

\begin{tabular}{|c|c|c|c|c|c|c|}
\hline \multirow[b]{2}{*}{$\begin{array}{l}\text { Cluster thinning } \\
\text { treatments }\end{array}$} & \multicolumn{6}{|c|}{ Timing of a fungicide application } \\
\hline & Control & $\begin{array}{c}\text { Full } \\
\text { Bloom }\end{array}$ & $\begin{array}{l}\text { Pre- } \\
\text { close }\end{array}$ & Veraison & \begin{tabular}{|l|} 
Bloom \\
+ Preclose \\
+ Veraison \\
\end{tabular} & Mean \\
\hline \multicolumn{7}{|c|}{ Disease incidence (Diseased clusters \%) ${ }^{\mathrm{a}}$} \\
\hline cluster thinning ${ }^{b}$ & 37.33 & 22.50 & 25.37 & 27.84 & 14.33 & $25.47^{\star}$ \\
\hline without cluster thinning & 46.67 & 34.47 & 37.67 & 39.34 & 29.87 & 37.60 \\
\hline Means & 42.00 & $29.98^{*}$ & $31.52^{*}$ & $33.59^{*}$ & $22.10^{*}$ & \\
\hline \multicolumn{7}{|c|}{ Disease severity (Percent rot per cluster) ${ }^{a}$} \\
\hline cluster thinning ${ }^{b}$ & 30.14 & 5.13 & 6.87 & 7.97 & 3.87 & $10.79^{*}$ \\
\hline without cluster thinning & 43.58 & 8.37 & 9.46 & 10.24 & 5.76 & 15.48 \\
\hline Means & 36.86 & $6.75^{*}$ & $8.17^{*}$ & $9.11^{*}$ & $4.82^{*}$ & \\
\hline \multicolumn{7}{|c|}{ Yield/Vine (Kg) ${ }^{\mathrm{a}}$} \\
\hline cluster thinning ${ }^{b}$ & 7.00 & 9.30 & 8.00 & 8.63 & 10.36 & $8.69^{\star}$ \\
\hline without cluster thinning & 5.24 & 7.70 & 7.00 & 6.86 & 8.24 & 7.02 \\
\hline Means & 6.12 & $8.50^{*}$ & $7.50^{*}$ & $7.75^{\star}$ & $9.30^{*}$ & \\
\hline \multicolumn{7}{|c|}{$\begin{array}{l}\text { a=Results are expressed as an average of three replicates means differences with } \\
\text { orthogonal contrasts. Figures followed by an asterisk denote a significant }(P< \\
\text { 0.01) effect from that treatment }\end{array}$} \\
\hline
\end{tabular}


The obtained results during 2006 (Table,4) indicate that disease incidence was significantly reduced from $46.67 \%$ in the control treatment to $37.33 \%$ when clusters were thinned. Cluster thinning also significantly decreased disease severity. Data showed a reduction in disease severity from $15.48 \%$ per cluster in the control treatment to $10.79 \%$ per cluster in the cluster thinning treatment.

Incidence and severity of bunch rot disease were relatively low due to summer pruning. Orthogonal contrasts identified significant difference resulting from summer pruning treatments in the first season (Table 5). The mean subplot effects of summer pruning treatments showed that bunch rot incidence percentage was significantly reduced from 38,67 to $8.33,13.87$, 14.47 and $23.13 \%$ in the control, the treatment of (leaf removal + shoot removal + topping), leaf removal, shoot removal and topping treatments, respectively.

Table (5): Effect of summer pruning practices and fungicide application on the incidence and severity of bunch rot disease and yield of grapevine cv. Thompson Seedless (During season, 2005).

\begin{tabular}{|c|c|c|c|c|c|c|}
\hline \multirow[b]{2}{*}{$\begin{array}{l}\text { Fungicide } \\
\text { Treatments }\end{array}$} & \multicolumn{6}{|c|}{ Summer pruning practices $^{c}$} \\
\hline & Control & $\begin{array}{l}\text { Leaf } \\
\text { removal }\end{array}$ & $\begin{array}{c}\text { Shoot } \\
\text { removal }\end{array}$ & Topping & $\begin{array}{c}\text { Leaf } \\
\text { removal } \\
\text { +shoot } \\
\text { removal } \\
\text { +Topping }\end{array}$ & Mean \\
\hline \multicolumn{7}{|c|}{ Disease incidence (Diseased clusters \%) ${ }^{\mathrm{a}}$} \\
\hline Sprayed ${ }^{\mathrm{b}}$ & 38.67 & 13.87 & 14.47 & 23.13 & 8.33 & $19.69^{*}$ \\
\hline Non sprayed & 50.33 & 26.18 & 30.67 & 34.67 & 18.26 & 32.02 \\
\hline Means & 44.50 & $20.03^{*}$ & $22.57^{*}$ & $28.9^{*}$ & $13.30^{*}$ & \\
\hline \multicolumn{7}{|c|}{ Disease severity (Percent rot per cluster) } \\
\hline Sprayed ${ }^{\mathrm{b}}$ & 18.34 & 4.87 & 5.97 & 7.18 & 3.43 & $07.96^{*}$ \\
\hline Non sprayed & 34.00 & 6,17 & 8.14 & 9.24 & 5.87 & 12.68 \\
\hline Means & 26.17 & $5.52^{*}$ & $7.06^{\star}$ & $8.21^{*}$ & $4.65^{\star}$ & \\
\hline \multicolumn{7}{|c|}{ Yield/Vine $(\mathrm{Kg})^{\mathrm{a}}$} \\
\hline Sprayed ${ }^{b}$ & 7.00 & 10.24 & 10.87 & 11.20 & 13.5 & $10.56^{*}$ \\
\hline Non sprayed & 6.33 & 8.87 & 7.53 & 9.24 & 11.34 & 08.66 \\
\hline Means & 6.67 & $9.56^{*}$ & $9.20^{*}$ & $10.22^{*}$ & $12.42^{*}$ & \\
\hline
\end{tabular}

${ }^{a}=$ Results are expressed as an average of three replicates means differences with

orthogonal contrasts. Figures followed by an asterisk denote a significant $(P<0.01)$ effect from that treatment

${ }^{b}=$ Sprayed with Euparen M at $200 \mathrm{~g} / 100$ L.W

c= Summer pruning practices

A fungicide application with summer pruning treatments was more effective in reducing disease incidence than the summer pruning treatment alone (without using fungicide).

Disease severity of bunch rot was also influenced by summer pruning treatment in the subplots and by fungicides in the main plot ( Table,5). Bunch rot severity was significantly reduced from 18.34 to $3.43,4.87,5.97$ and $7.18 \%$ in the control, the treatment of (leaf removal, shoot removal and toping 
treatments), leaf removal, shoot removal and topping treatments, respectively. Fungicide applications further reduced bunch rot severity.

The greatest reduction was occurred in the treatment of summer pruning (leaf removal + shoot removal + topping) where severity was reduced from 26.17 to $4.65 \%$ on the average. Yields were significantly increased under the effect of treatments that reduced the infection by bunch rot. The average weights of clusters harvested from vines treated with summer pruning treatments and from untreated control vines subplots were 9.56, 9.20, 10.22, $12.42 \mathrm{and} 6.67 \mathrm{~kg} \mathrm{/} \mathrm{vine} \mathrm{for} \mathrm{leaf} \mathrm{removal,} \mathrm{shoot} \mathrm{removal,} \mathrm{topping,} \mathrm{the}$ treatment of (Leaf removal + shoot removal + topping) and the untreated control, in subplot and by fungicides in the main plot, respectively in the first season.

Table (6): Effect of summer pruning practices and a fungicide application on the incidence and severity of bunch rot disease and yield of grapevine cv. Thompson Seedless (During season, 2006).

\begin{tabular}{|c|c|c|c|c|c|c|}
\hline \multirow[b]{2}{*}{$\begin{array}{l}\text { Fungicide } \\
\text { Treatments }\end{array}$} & \multicolumn{6}{|c|}{ 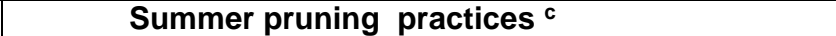 } \\
\hline & Control & $\begin{array}{l}\text { Leaf } \\
\text { removal }\end{array}$ & $\begin{array}{c}\text { Shoot } \\
\text { removal }\end{array}$ & Topping & \begin{tabular}{|c|} 
Leaf \\
removal \\
+shoot \\
removal \\
+Topping
\end{tabular} & Mean \\
\hline & \multicolumn{6}{|c|}{ Disease incidence (Disease clusters \%) } \\
\hline Sprayed b & 36.33 & 13.00 & 15.33 & 20.53 & 9.12 & $18.86^{*}$ \\
\hline Non sprayed & 48.53 & 25.87 & 30.97 & 32.87 & 19.67 & 31.58 \\
\hline Means & 42.43 & $19.44^{*}$ & $23.15^{\star}$ & $26.7^{*}$ & $14.39^{*}$ & \\
\hline \multicolumn{7}{|c|}{ Disease severity (Percent rot per cluster) ${ }^{a}$} \\
\hline Sprayed b & 20.53 & 4.36 & 5.53 & 7.28 & 3.67 & $08.27^{*}$ \\
\hline Non sprayed & 36.76 & 6.22 & 7.97 & 9.87 & 6.00 & 13.36 \\
\hline Means & 28.65 & $5.29^{*}$ & $6.75^{*}$ & $8.57^{*}$ & $4.83^{*}$ & \\
\hline \multicolumn{7}{|c|}{ Yield/Vine $(\mathrm{Kg})^{\mathrm{a}}$} \\
\hline Sprayed ${ }^{\mathrm{b}}$ & 7.53 & 10.83 & 10.56 & 11.00 & 12.36 & $10.46^{*}$ \\
\hline Non sprayed & 6.12 & 7.97 & 8.24 & 9.12 & 10.33 & 8.36 \\
\hline Means & 6.83 & $9.40^{*}$ & $9.40^{*}$ & $10.06^{*}$ & $11.35^{*}$ & \\
\hline
\end{tabular}

${ }^{a}=$ Results are expressed as an average of three replicates means differences with orthogonal contrasts. Figures followed by an asterisk denote a significant $(P<0.01)$ effect from that treatment

b =Sprayed with Euparen M at $200 \mathrm{~g} / 100$ L.W

$\mathrm{C}=$ Summer pruning practices

In the second season, it is clear from the data (Table, 6) that all treatments showed the same trend of the data obtained in the first season. The mean subplot effects of summer pruning practices showed that bunch rot incidence percentage was significantly reduced from 42.43 to $14.39,19.44$ , 23.15 and $26.7 \%$ in the control, the treatment of (leaf removal + shoot removal + Topping), leaf removal, shoot removal and Topping treatments on the average, respectively. Fungicide applications in summer pruning practices treatments were more effective in reducing disease incidence than in the summer pruning practices treatments without using fungicide. 
Disease severity of bunch rot also was influenced by summer pruning practices treatments in subplot and by fungicide applications in the main plot (Table, 6). Bunch rot severity was significantly reduced from 28.65 to 4.83 , $5.29,6.75$ and $8.57 \%$ in the control, the treatment of (leaf removal + shoot removal + Topping), leaf removal, shoot removal and topping treatments, respectively. Fungicide applications further reduced bunch rot severity. The greatest reduction was occurred in the treatment of (leaf removal +shoot removal +Topping), where severity was reduced from 28.65 to $4.83 \%$ on the average.

Yields were significantly increased under the effect of treatments that reduced the infection by bunch rot. The average weight of clusters harvested from vines treated in subplot with leaf removal, shoot removal, topping, the treatment of (leaf removal + shoot removal and topping) and from the control( vines without summer pruning practices) and by fungicides in the main plot was $10.83,10.56,11.00,12.36$ and $7.53 \mathrm{Kg} / \mathrm{vine}$, respectively in the second season. While, the average weights of clusters harvested from vines treated in subplot with leaf removal, shoot removal, topping, the treatment with (leaf removal + shoot removal and topping) and the control vines (without summer pruning practices) and without fungicides in the main plot recorded 7.97, $8.24,9.12,10.33,6.12 \mathrm{Kg} / \mathrm{vine}$, respectively in the second season.

\section{DISCUSSION}

Controlling bunch rot disease of grape through the use of summer pruning practices is a viable alternative to repeated gibberellin applications. Data from field trials showed that summer pruning practices( leaf removal + shoot removal and topping) resulted in excellent disease control even under conditions otherwise causing severe rot. Other treatments used in this study also reduced the incidence and severity of bunch rot but less than the treatment with leaf removal + shoot removal and topping. The discrepancy in data obtained from both treatment with (leaf removal + shoot removal + topping) and other treatments can be explained partially on the basis of the stage of plant growth when these treatments were performed.

Besides the main effect of gibberellin application as a strong growth regulator, it is also has some effects on disease susceptibility of grapes through altered metabolism of the host. In this concern, Branas (1967) discussed the effect of several treatments including fungicides and gibberellin as individual or mixed treatments on the infection of grapes by $B$. cinerea .

Mahrous (1988) recorded that applying GA4+7 at $10 \mathrm{ppm}$ was more effective against grape berries rot caused by Botryodiplodia theobromae, Aspergillus niger, Alternaria sp. and Penicillium sp. of Roumi Red under vineyard conditions.

Farag (1992) recorded that gibberellic acid affected the sporulation of Aspergillus flavus, Alternaria alternata and Penicillium expansum and sclerotia formation by Botrytis cinerea.

Cluster thinning has potential for use in bunch rot control strategies. Although disease control was minimal when fungicides were not used, 
excellent control was achieved when fungicides were applied to vines in which cluster berries were thinned at cluster set. These results take the same line with Cherif and Boubaker(1998) and Houma et al (1998) who found that the thinning of berries reduced significantly Botrytis bunch rot development. Also, Smithyman et al (1998) found that the delaying cluster thinning until after fruit set decreased the incidence of Botrytis bunch rot.

Fungicides currently, are used widely in controlling bunch rot disease on grapes, but generally become less effective as the grapevine matures because of heavy canopy growth and bunch closing. Usually, by the third fungicide application at or near veraison stage, it becomes virtually impossible to penetrate the canopy with enough volume to adequately protect the cluster targets. Preliminary spray efficiency data have shown that leaf removal increased spray coverage within the canopy (Gubler et al., 1987).

Results of fungicides timing trials also lead to question the need for a fungicide application at bloom. The obtained data from this trial showed a significant difference in disease control between single fungicide application made at bloom or preclose or veraison and three sprays at the timing described. The obtained results are in agreement with those obtained by McClellan and Hewitt( 1973)who reported that applications at bloom were most effect. They based this on the ability of $B$. cinerea to infect immature grape berries via senescing flower parts resulting in latent infection. Savage and Sall (1984) however, were unable to detect the presence of the fungus in the immature berries. Fungicides alone do not provide a adequate protection against Botrytis cinerea during severe disease pressure. By integrating the cultural control practice of summer pruning with chemical control or with gibberellin application, this will provide adequate protection against grapevine bunch rot disease.

\section{REFERENCES}

Anonymous. (2005). Annual Report of Agric. Statistical Dept. Egyptian Min. of Agric.A.R.E.(In Arabic).

Bettiga, L.J., Gubler, W.D., Marois, J.J. and Bledsoe, A.M. (1989). Integrated control of Botrytis bunch rot of grape. Calif. Agric. 43:9-11.

Boccalon, W.; S. Bressan and P. Mutton (2005). Chemical thinning of Pinot Grigio for quality grapes. Notiziario ERSA. 18 (1): 33-38.

Branas, J.(1967). Control of grey mold. Progress Agric. Vitic., 84:365-376.

Cherif, M. and A. Boubaker (1998). Effects of cultural practices, fungicides and bio control agents on Botrytis bunch rot of grapes. Bulletin- OILB/SROP. 21(6): 41-51.

Dokoozlian, N.K.; N.C. Ebisuda and J.M. Hashim (2001).Gibberellic acid bloom sprays reduce fruit set and improve pack able yield of ' Autumn Royal ' table grapes. Journal of American Pomological Society. 55(1): 52-57.

English, J.T.; C.S. Thomas; J.J. Marois and W.D. Gubler.(1989). Influence of grapevine canopies associated with leaf removal and control of Botrytis bunch rot. Phytopathology 79: 395-401. 
English, J.H.; Kaps, M.L.; Moore, J.F.; Hill, J. and Nakova, M. (1993). Leaf removal for control of Botrytis bunch rot of grapes in the Midwestern United States. Plant Disease. 77 (12): 1224-1227.

Farag, M. R. (1992). Assessment of environmental hazards of post-harvest grape disease. PH.D. Thesis, Department of Agric. Science, Institute of Environmental Studies and Research, Ain Shams Univ, Egypt, 231 p.

Ferree, D.C.; N.A. Ellis; S.J. McArthney, M.V. Brown and D.M. Scurlock (2003). Comparison of fungicide, leaf removal and gibberellic acid on development of grape clusters and botrytis bunch rot of ' Vignoles' and ' Pinot Gris'. Small Fruits Review. Food Products Press, Binghamton, USA.2:4, 3-18.

Gubler, W.D.; J.J. Marois; A.M. Bledsoe and L.J. Bettiga. (1987). Control of botrytis bunch rot of grape with canopy management. Plant Disease. 71:599-601.

Hopping, M.E. (1976). Effect of bloom applications of gibberellic acid on yield and bunch rot of the wine grape "Seible 5455" Newzealnd. J. Exp. Agric. 4(1): 103-107. (Rev. of Plant Patho. 55:5299).

Houma , R.A.; M. Cherif and A. Boubaker.(1998). Effect of nitrogen fertilization, green pruning and fungicide treatment on Botrytis bunch rot of grapes . Journal of Plant Pathology $80: 2,115-124$.

Kumar, R. and O.P. Gupta.(1987). Effect of pre-harvest application of fungicide, growth regulators and calcium nitrate on the storage behavior of Perlette grapes at low temperature. Haryana Agricultural University Journal of Research. 17; 30-38.

Mahadevan, A.(1984).Growth Regulators, Microorganisms and Diseased Plants. Oxford \& IBH Publishing Co., New Delhi pp.466.

Mahrous, H. A. H. (1988). Effect of some growth regulations on vegetative growth, fruiting and some fungal diseases of grapes. M. Sc. Thesis, Fac. Agric. Suez Canal Univ., Egypt.

McClellan, W.C. and Hewit. W.B. (1973). Early Botrytis rot of grapes: Time of infection and latency of Botrytis cinerea In Vitus vinifera $L$. Phytopathology 63:1151-1157.

Sarig, P.; Y. Zutkhi; N. Lisker; Y. Shkelerman and R. Ben-Arie (1998). Natural and induced resistance of table grapes to bunch rots. Acta Horticulture. 464, 65-70.

Savage, S.D. and Sall, M.A. (1984). Botrytis bunch rot of grapes: Influence of trellis type and canopy microclimate. Phytopathology, 74: 65-70.

Smart, R.E. (1985). Principles of grapevine canopy microclimate manipulation with implications for yield and quality. A review. Am. J. Enol. Vitic. 36: 230-239.

Smithyman , R.P. ;G.S.Howell and D.P. Miller (1998). The use of competition for carbohyedryet among vegetative and reproductive sinks to reduce fruit set and botrytis bunch rot in seyval balanc grapevines. American Journal of Enology and Viticulture ,49:2,163-170.

Snedcor, G.W. and Cochran, W. G.(1972). Statistical Methods. $6^{\text {th }}$ ed Ames, lowa, the lowa State Univ. Press 
Stapleton, J.J. and Grant, R.S. (1992). Leaf removal for nonchemical control of the summer bunch rot complex of wine grapes in the san Joaquin Valley. Plant Dis. 76: 205-208.

Thomas, C.S., Marois, J.J. and English J.T. (1988). The effect of wind speed, ternperature and relative humidity on development of aerial mycelium and conidia of Botrytis cinerea on grape. Phytopathology 78: 260-265.

Tiku, A.K.; Rita-Langer and V.K.K. Naz (2005). Marveles of sodium carbonate on Perlette grapes. Advances in Plant Sciences. 18(1): 417420.

Weaver ,R.J.(1976).Grape Growing. A Willey Interscience Publication.Johen Willey \& Sons, New York. pp. 371.

Wolf, T.K.; R.M. Pool and L.R. Mattick (1986). Responses of young Chardonnay grapevines to shoot tipping, ethephon and basal leaf removal. American Journal of Enology and Viticulture. 37(4): 263268.

Wolf, T.K. B.W. Zoecklein; M.K. Cook and C.K. Cottingham (1990). Shoot topping and ethephone effects on White Riesling grapes and grapevines. American Journal of Enology and Viticulture. 41(4): 330341

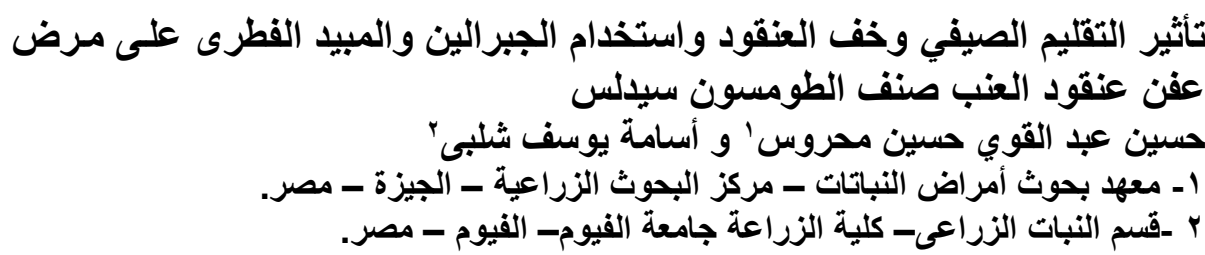

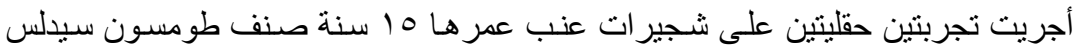

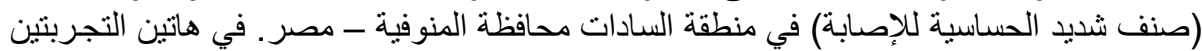

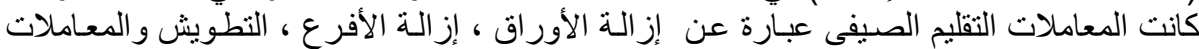

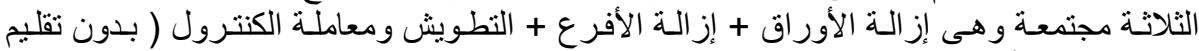

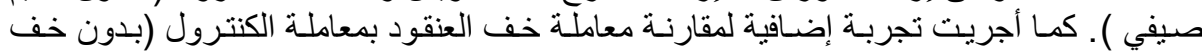

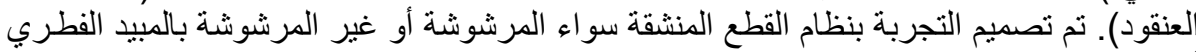

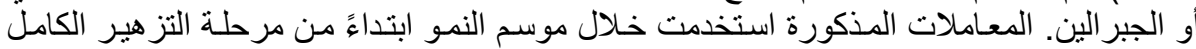

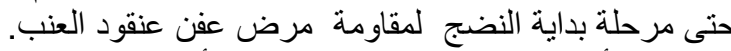

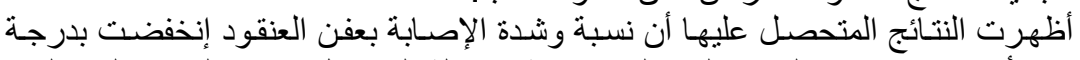

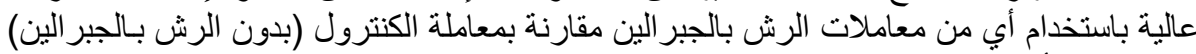

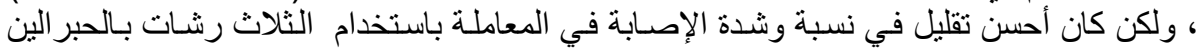

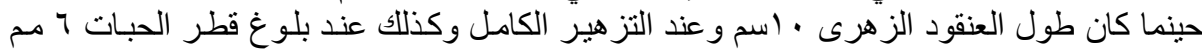
و التى ينم فيها التقليم الصيفي.

في التجربة الإضافية قلل خف العنقود أيضاً نسبة وشدة الإصابة في معاملة الكنترول غير المرشوشة العنة

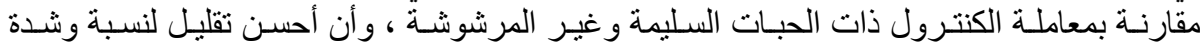

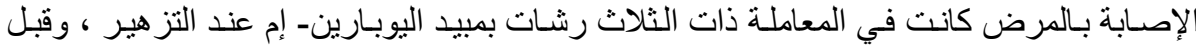

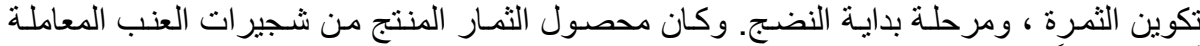
أعلى معنوياً في كلا موسمي الدراسة مقارنة بمحصول شجير النير ات العنب غير المعاملة. 